\title{
The study of humic acid foliar application on physiological and biochemical changes in wheat under irrigation withholding at different growth stages
}

\author{
Tohidi HR \\ Department of Agronomy, College of Agriculture, Varamin-Pishva Branch, Islamic Azad University, Varamin, \\ Iran
}

[Received: December 02, 2014; Accepted: January 05, 2015]

\begin{abstract}
In order to study effect of humic acid (HA) foliar application and limited irrigation, on physiological and biochemical characteristics of wheat an experiment was conducted in research field of Varamin, Iran during 2012 growing season. The experimental design was laid out in a randomized complete block with a split plots arrangement of treatments in three replications. Main plots included four different levels of irrigation (complete irrigation, irrigation withholding at stem elongation stage, irrigation withholding at flowering stage and irrigation withholding at seed setting stage) and three different concentration of HA foliar application (0, 150 and 300$)$ was allocated to subplots. The results showed that irrigation withholding conditions in different growth stages significantly decreased seed yield and total chlorophyll content but by contrast increased electrolyte leakage, antioxidant enzymes activity and lipid and protein peroxidation. It appears that HA act in plants via a specific form of stress that is detected by anti-stress defense systems in plants. These HA applied to plants can protect against water stress in degraded soils.
\end{abstract}

Keywords: Humic acid, wheat, irrigation withholding, seed yield, antioxidant enzymes.

\section{INTRODUCTION}

Drought stress significantly limits plant growth and crop productivity. The fact that water stress effects on growth and yield are genotype-dependent is well known [1]. Under conditions of water stress and other types of environmental stress, reactive oxygen species (ROS), such as superoxide anion radicals, hydrogen peroxide and hydroxyl radicals, are generated [2]. These free radicals can damage essential membrane lipids as well as proteins and nucleic acids [3]. Plant cells contain an array of protection mechanisms and repair systems that can minimize the occurrence of oxidative damage caused by reactive oxygen species (ROS) [4]. Mechanisms of active oxygen species detoxification exist in all the plants and include activation of enzymatic (superoxide dismuatase, catalase,ascorbat peroxidase, peroxidase, glutathione reductase [5]. Humic acid (HA) is the active constituent of organic fertilizers and its application may represent an alternative to conventional soil fertilization and a prompt source of $\mathrm{N}$, especially in semi-arid conditions [6,7]. The humic substances, the major component of soil organic matter, have both direct and indirect effects on plant growth [8]. Humic acids can protect plants in water deficientsoils, On the other hand recently, a new mode of action for HA suggests that HA can cluster in roots to affect transpiration and, therefore, the hydraulic conductivity of the roots via colloidal stress [9]. Effects on antioxidative defense mechanisms, reporting the stimulation of catalases (CAT) and the generation of reactive oxygen species (ROS) that act as intermediaries in plant growth [10]. Hence in this field experiment, an attempt was made to investigate the effect of humic acid foliar application on yield and antioxidant enzymes activity of wheat plants under compete irrigation and irrigation withholding at different growth stages.

\section{MATERIALS AND METHODS}

In order to study effect of humic acid foliar application and limited irrigation, on physiological and biochemical characteristics of wheat an experiment was conducted in research field of Varamin, Iran during 2012 growing season. Site of study was situated at $35^{\circ}, 19^{\prime} \mathrm{N}$ and $51^{\circ}, 39^{\prime} \mathrm{E}, 900 \mathrm{~m}$ above sea level. Before beginning of experiment, soil samples were taken in order to determine the physical and chemical properties. A composite soil sample was collected at a depth of 0-30 cm. It was air dried, crushed, and tested for physical and chemical properties. The research field had a clay loam soil. Details of soil properties are shown in Table 1 . 
After plow and disk, plots were prepared. The experimental design was carried out in a randomized complete block with a split plot arrangement of treatments in three replications. Main plots included
Antioxidant enzyme activity assay

Catalase activity was estimated by the method of Cakmak and Horst [12]. Superoxide dismutase activity was determined according to the method of

Table 1: Soil properties of the experimental site

\begin{tabular}{lllllllll}
\hline Depth & $\left.\mathrm{EC}(\mathrm{ds} \mathrm{m})^{-1}\right)$ & $\mathrm{pH}$ & $\begin{array}{l}\text { O.C } \\
(\%)\end{array}$ & T.N.V $(\%)$ & $\begin{array}{l}\mathrm{K} \\
(\mathrm{ppm})\end{array}$ & $\mathrm{P}(\mathrm{ppm})$ & $\mathrm{N}(\%)$ & Texture \\
\hline $0-30 \mathrm{~cm}$ & 3.9 & 7.52 & 1.12 & 20.8 & 395.4 & 11.9 & 0.07 & $\begin{array}{l}\text { Clay } \\
\text { loam }\end{array}$ \\
\hline
\end{tabular}

four different levels of irrigation (complete irrigation, irrigation withholding at stem elongation stage, irrigation withholding at flowering stage and irrigation withholding at seed setting stage) and three different concentration of HA foliar application $(0$, 150 and 300) was allocated to subplots. Each sub plot consisted 12 rows, $5 \mathrm{~m}$ long with $20 \mathrm{~cm}$ spaced between rows and $5 \mathrm{~cm}$ distance between plants on the rows. For determination of seed yield, the
Giannopolitis and Ries [13]. Glutathione peroxidase activity was measured according to method of Paglia and Valentine [14].

\section{Lipid peroxidation assay}

The level of membrane damage was determined by measuring MDA as the end product of peroxidation of membrane lipids [15].

Table 2: Analysis of variance on wheat attributes affected by irrigation withholding in different growth stages and humic acid foliar application

\begin{tabular}{|c|c|c|c|c|c|c|c|c|c|}
\hline S.O.V & df & Seed yield & $\begin{array}{l}\text { Total } \\
\text { chloroph } \\
\text { yll }\end{array}$ & $\begin{array}{l}\text { Membrane } \\
\text { stability }\end{array}$ & $\begin{array}{l}\text { Superoxide } \\
\text { dismutase }\end{array}$ & Catalase & $\begin{array}{l}\text { Glutathione } \\
\text { peroxidase }\end{array}$ & $\begin{array}{l}\text { Malondi } \\
\text { aldehyde }\end{array}$ & $\begin{array}{l}\text { Dityros } \\
\text { ine }\end{array}$ \\
\hline Replication & 2 & 407749.71* & ${ }^{\mathrm{ns}} \mathbf{0 . 6 8}$ & ${ }^{\mathrm{ns}} \mathbf{3 1 5 . 7 5}$ & ${ }^{\mathrm{n}} \mathbf{2 8 . 1 3}$ & ${ }^{\mathrm{ns}} 512.23$ & ${ }^{\mathrm{n}} \mathrm{965.01}$ & ${ }^{\mathrm{ns}} \mathbf{0 . 0 1}$ & ${ }^{\mathrm{ns}} \mathbf{0 . 0 0 2}$ \\
\hline Irrigation & 3 & $\begin{array}{l}* * \\
20370278.3\end{array}$ & $131.8 * *$ & $178652.6^{* *}$ & $278676.52 * *$ & $20517.74 * *$ & $19760.04 * *$ & $67.32 * *$ & $\begin{array}{l}* * \\
24.42\end{array}$ \\
\hline Error (a) & 6 & 77788.51 & 1.01 & 132.74 & 98.29 & 678.52 & 1027.75 & 0.01 & 0.003 \\
\hline $\begin{array}{l}\text { Humic acid } \\
\text { foliar } \\
\text { application }\end{array}$ & 2 & ${ }^{\mathrm{ns}} 39791.64$ & ${ }^{\mathrm{ns}} 4.9$ & $8600.99 * *$ & $15219.59 * *$ & ${ }^{\mathrm{ns}} 1818.24$ & 7511.16** & $0.74 * *$ & $1.03 * *$ \\
\hline Interaction & 6 & ${ }^{\mathrm{ns}} \mathbf{1 0 6 7 8 6 . 5 7}$ & ${ }^{\mathrm{ns}} \mathbf{1 . 2}$ & $1595.54 *$ & ns 707.05 & ${ }^{\mathrm{ns}} 947.71$ & ${ }^{\mathrm{ns}} 1183.41$ & ${ }^{\mathrm{ns}} \mathbf{0 . 0 8}$ & $0.04 *$ \\
\hline Error (b) & 16 & 114882.04 & 11.85 & 468.68 & 453.89 & 749.11 & 1165.48 & 0.03 & 0.01 \\
\hline C.V & & 4.76 & 11.84 & 2.33 & 2.69 & 17.06 & 20.04 & 1.57 & 1.84 \\
\hline
\end{tabular}

samples consisted of $3 \mathrm{~m}$ along the center row of each plot, discarding two rows on the border. The remaining plants were cut at ground level, yield was determined with the experimental combine harvester machine. The humic acid foliar application was applied with a pressurized backpack sprayer (12 1 capacity) calibrated to deliver $1000 \mathrm{l} \mathrm{ha}^{-1}$ of spray solution. Sprayer was equipped with a spiral solid cone spray nozzle. At the end of growing season crop were harvested and seed yield and biological yield were assayed.

Membrane stability assay

Leaf samples $(0.5 \mathrm{~g})$ were immersed into $10 \mathrm{ml}$ of -2 bar mannitol solution (14.7 g mannitol per liter) and after $24 \mathrm{~h}$ electrical conductivity of the solution was measured.

\section{Chlorophyll assay}

Chlorophyll was extracted in $80 \%$ acetone from the leaf samples according to the method of Arnon [11].
Protein peroxidation assay

A standard dityrosine sample was prepared according to Amado et al. [16].

\section{Statistical analysis}

All data were subjected to SAS software [17]. Duncan's multiple range tests was used for statistical differences between treatment means and controls. Comparisons with $\mathrm{P}$ values 0.05 were considered significantly different.

\section{RESULTS}

Analysis of variance showed that the effect of irrigation withholding in different growth stages was significant on all traits experiment. Also the effect of humic acid foliar application was significant on all measured traits experiment except for seed yield, total chlorophyll content and catalase enzyme activity (Table 2). Interaction of experimental factors (irrigation withholding in different growth stages $x$ 
humic acid foliar application) was not significant on all measured traits experiment except for membrane stability and Dityrosine. As can be seen from table 3, seed yield decreased as result of irrigation withholding at stem elongation, flowering and seed setting stages at by $10.56 \%, 40.37 \%$ and $21.98 \%$, respectively with compared complete irrigation treatment conditions. The stress treatments decreased
Furthermore, water deficit decreased seed yield via decrease in photosynthesis and seed number per spike. Similar results are accessible published by other researcher [19]. Our results showed a decrease in the chlorophyll content under water deficit stress (Table 2). It is consistent with the results of Yari et al. [20] suggesting that moisture stress reduces leaf chlorophyll content. This decrease of leaf

Table 3: Comparison of main means wheat attributes affected by irrigation withholding in different growth stages and humic acid foliar application

\begin{tabular}{|c|c|c|c|c|c|c|c|c|}
\hline Treatments & $\begin{array}{l}\text { Seed } \\
\text { yield } \\
\left(\mathrm{kg} \cdot \mathrm{ha}^{-1}\right)\end{array}$ & $\begin{array}{l}\text { Total } \\
\text { chloro } \\
\text { phyll } \\
\left(\mathrm{mg} . \text { lit }^{-}\right. \\
\left.{ }^{1}\right)\end{array}$ & $\begin{array}{l}\text { Membra } \\
\text { ne } \\
\text { stability } \\
\left(\mu \mathrm{s} \mathrm{cm}^{-}\right. \\
\left.{ }^{-}\right)\end{array}$ & $\begin{array}{l}\text { Superox } \\
\text { ide } \\
\text { dismuta } \\
\text { se } \\
(\Delta \mathrm{A} / \mathrm{mg} \\
\text { pro.min } \\
\left.{ }^{1}\right)\end{array}$ & $\begin{array}{l}\text { Catalase } \\
(\Delta \mathrm{A} / \mathrm{mg} \\
\text { pro.min } \\
\left.{ }^{1}\right)\end{array}$ & $\begin{array}{l}\text { Glutathione } \\
\text { peroxidase } \\
(\Delta \mathrm{A} / \mathrm{mg} \\
\left.\text { pro. } \mathrm{min}^{-1}\right)\end{array}$ & $\begin{array}{l}\text { Malondi } \\
\text { aldehyd } \\
\text { e } \\
\text { (nmol } \\
\text { g-1 FW) }\end{array}$ & $\begin{array}{l}\text { Dityrosi } \\
\text { ne } \\
\text { (nmol } \\
\text { g-1 } \\
\text { FW) }\end{array}$ \\
\hline \multicolumn{9}{|l|}{ Irrigation } \\
\hline $\begin{array}{l}\text { Complete } \\
\text { Irrigation }\end{array}$ & $8707.8 \mathrm{a}$ & a32.66 & d763.01 & $\mathrm{d} 621.13$ & c98.08 & c105.16 & c8.25 & $\mathrm{d} 4.98$ \\
\hline $\begin{array}{l}\text { Irrigation } \\
\text { withholdin } \\
\mathrm{g} \text { at stem } \\
\text { elongation }\end{array}$ & $7788 b$ & a31.66 & b954.47 & b813.10 & b169.18 & ab188.44 & b13.48 & b6.68 \\
\hline $\begin{array}{l}\text { Irrigation } \\
\text { withholdin } \\
\mathrm{g} \text { at } \\
\text { flowering }\end{array}$ & $5192.2 \mathrm{~d}$ & b27.62 & a1100.59 & $\mathrm{a} 1026.68$ & a214.05 & a215.14 & a14.05 & a8.76 \\
\hline $\begin{array}{l}\text { Irrigation } \\
\text { withholdin } \\
\mathrm{g} \text { at seed } \\
\text { setting } \\
\text { stages }\end{array}$ & $6793.7 \mathrm{c}$ & $\mathrm{b} 24.35$ & $\mathrm{c} 884.85$ & c701.53 & b160.16 & b172.36 & b13.56 & c5.67 \\
\hline $\begin{array}{l}\text { Humic } \\
\text { acid foliar } \\
\text { application }\end{array}$ & & & & & & & & \\
\hline $\begin{array}{l}\text { Untreated } \\
(0 \mathrm{ppm})\end{array}$ & a7183.8 & a28.38 & a950.09 & c758.62 & a 154.92 & b150.10 & a12.59 & a6.80 \\
\hline $\begin{array}{l}\text { Treated } \\
(150 \mathrm{ppm})\end{array}$ & a7106.1 & a29.19 & b930.01 & b784.22 & a151.72 & b162.46 & b12.33 & b6.55 \\
\hline $\begin{array}{l}\text { Treated } \\
(300 \mathrm{ppm})\end{array}$ & a7071.4 & a29.64 & c897.07 & a828.98 & a174.46 & a198.27 & c12.09 & c6.21 \\
\hline
\end{tabular}

Treatment means followed by the same letter within each common are not significantly different $(P<0.05)$ according to Duncan's Multiple Range test

the number of days required for wheat to reach $50 \%$ flowering or maturity, by an average of 4-7 days, if compared with the unstressed control. Similar findings have been reported for faba bean (Vicia faba L.), by Mwanamwenge et al. [18]. Acceleration of flowering and maturity probably contributed to reduce the impact of drought stress wheat. chlorophyll under water deficit is due to the destruction of chlorophyll pigments and the instability of the pigment-protein complex [21].

According to table 3 the highest electrolyte leakage was occurred when wheat plants were treated with irrigation withholding at flowering stage. Electrolyte 
leakage decreased as result of humic acid foliar application when these treatments compared with untreated humic acid foliar application (Table 3). Under irrigation withholding at flowering and seed setting stages electrolyte leakage decreased as result of humic acid foliar application with 300 ppm when these treatments compared with untreated humic acid foliar application in this condition (Table 4). Jabari et al. [22] indicated that cell walls were destroyed under drought stress because stomata closure under drought conditions decreased carbon dioxide fixation, while photo reactions and compositions like fats, proteins, carbohydrates and nucleic acids [23]. As a result, fatty peroxides destroy cell membrane [24].

Also the result showed that the highest superoxide dismutase, catalase and Glutathione peroxidase enzyme activity were obtained from Irrigation withholding at flowering stage (Table 3). The combined action of SOD and CAT converts the toxic $\mathrm{O}_{2}{ }^{--}, \mathrm{H}_{2} \mathrm{O}_{2}$ to water and molecular oxygen, averting the cellular damage under unfavorable conditions such as drought stress $[25,26]$. It was proved that the drought stress increases the production of reactive

Table 4: Interaction between irrigation withholding in different growth stages and humic acid foliar application on some attributes of wheat

\begin{tabular}{|c|c|c|c|c|c|c|c|c|c|}
\hline Treatments & $\begin{array}{l}\text { Humic acid foliar } \\
\text { application }\end{array}$ & $\begin{array}{l}\text { Seed } \\
\text { yield } \\
\left(\mathrm{kg} \cdot \mathrm{ha}^{-1}\right)\end{array}$ & $\begin{array}{l}\text { Total } \\
\text { chlorophy } \\
\text { ll } \\
\left(\mathrm{mg} \cdot \mathrm{lit}^{-1}\right)\end{array}$ & $\begin{array}{l}\text { Membran } \\
\text { e stability } \\
\left(\mu \mathrm{sm}^{-1}\right)\end{array}$ & 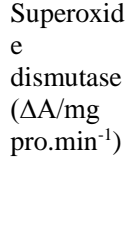 & $\begin{array}{l}\text { Catalase } \\
\left(\Delta \mathrm{A} / \mathrm{mg}^{-1}\right) \\
\text { pro.min } \mathrm{min}^{-1}\end{array}$ & $\begin{array}{l}\text { Glutathio } \\
\text { ne } \\
\text { peroxidas } \\
\text { e } \\
\left(\Delta \mathrm{A} / \mathrm{mg}^{-1}\right) \\
\left.\text { pro. } \mathrm{min}^{-1}\right)\end{array}$ & $\begin{array}{l}\text { Malon } \\
\text { dialdehy } \\
\text { de } \\
\left(\mathrm{nmolg}^{-1}\right. \\
\text { FW) }\end{array}$ & $\begin{array}{l}\text { Dityr } \\
\text { osine } \\
\text { (nmol } \\
\mathrm{g}^{-1} \\
\text { FW) }\end{array}$ \\
\hline
\end{tabular}

\begin{tabular}{ll}
\hline Irrigation & $\begin{array}{l}\text { Humic acid foliar } \\
\text { application }\end{array}$
\end{tabular}

Complete
Irrigation

Treated $(150 \mathrm{ppm})$
Treated $(300 \mathrm{ppm})$

$\mathrm{a} 8499.7$
$\mathrm{a} 8915.9$

$\mathrm{ab32.63}$
$\mathrm{a} 33.01$

h765.32

h752.6

\section{h624.1}

gh636.32

e97.52

de105.55 f8.24

dce111.04 f8.16

jk4.95

k4.88

\begin{tabular}{|c|c|c|c|c|c|c|c|c|c|}
\hline \multirow[t]{2}{*}{$\begin{array}{l}\text { Irrigation } \\
\text { withholding } \\
\text { at stem } \\
\text { elongation }\end{array}$} & Untreated $(0 \mathrm{ppm})$ & b7727.6 & ab31.15 & d964.69 & e773.11 & cb189.07 & dce151.91 & cb13.94 & d7.02 \\
\hline & Treated $(300 \mathrm{ppm})$ & b7888.7 & $a b 32.38$ & $\operatorname{de} 950$ & c860.69 & cb168.26 & a248.41 & e13.04 & f6.29 \\
\hline & Untreated $(0 \mathrm{ppm})$ & $\mathrm{d} 5290.7$ & $\operatorname{cb} 27.18$ & a1148.59 & b1000.45 & cb190.04 & $a b 196.54$ & a14.28 & b9.13 \\
\hline & Treated (150 ppm) & d4894.6 & $\operatorname{cb} 27.21$ & b1110.38 & b1016.2 & $a b 204.53$ & $a b 209.97$ & ab14.17 & c8.77 \\
\hline & Treated (300 ppm) & d5391.4 & cab28.47 & c1042.78 & $\mathrm{a} 1063.38$ & $\mathrm{a} 247.59$ & a238.91 & $\operatorname{cd} 13.71$ & c8.38 \\
\hline \multirow{3}{*}{$\begin{array}{l}\text { Irrigation } \\
\text { withholding } \\
\text { at seed }\end{array}$} & Untreated $(0 \mathrm{ppm})$ & c6801.2 & $\mathrm{c} 22.87$ & fe916.01 & g657.96 & $\operatorname{cd} 147.99$ & $\begin{array}{l}\text { dceb } \\
\mathbf{1 5 3 . 0 3}\end{array}$ & $\operatorname{cd} 13.78$ & g5.95 \\
\hline & Treated $(150 \mathrm{ppm})$ & c6785.5 & c25.46 & f895.63 & f691.1 & cb154.63 & cb169.33 & $\mathrm{d} 13.46$ & h5.75 \\
\hline & Treated $(300 \mathrm{ppm})$ & c6794.5 & c24.73 & g842.9 & e755.54 & cb177.86 & ab194.71 & d13.45 & i5.32 \\
\hline
\end{tabular}

Treatment means followed by the same letter within each common are not significantly different $(P<0.05)$ according to Duncan's Multiple Range test

electron transfer went on in their normal manner. Under such condition, NADP availability will be limited for electron acceptance. Therefore, oxygen can be an alternative electron acceptor which leads to the accumulation of poisonous oxygen species such as superoxide radicals $\left(\mathrm{O}_{2}\right)$, peroxide hydrogen $\left(\mathrm{H}_{2} \mathrm{O}_{2}\right)$ and hydroxyl radicals $\left(\mathrm{OH}^{-}\right)$. The accumulation of active oxygen species, which are produced under stress, damages many cell oxygen species (ROS) [27]. To scavenge these ROS, plants either synthesize different antioxidant compounds or activate antioxidant enzymes. Plants can detoxify ROS by up-regulating antioxidant enzymes, such as SOD, CAT and POX as well as some non-enzymatic antioxidant compounds. It is evident that high levels of antioxidants are related to plant water deficit tolerance [28, 29]. Similar results were reported under drought stress in wheat [30], 
Phaseolus acutifolius [31] and tomato plants [32]. Humic acid treatment with high concentration (300 ppm) increased superoxide dismutase, catalase and glutathione peroxidase enzyme activity (Table 3 ). Under irrigation withholding at different growth stages, humic acid foliar application with $300 \mathrm{ppm}$ increased antioxidant enzyme activity (Table 4). The hypothesis proposed by Asli and Neumann [9] can be justified by these results because colloidal stress may be one explanation for these plant responses to the presence of HA via oxidative stress mechanisms. As such, the theories proposed by other authors regarding the rupture of the HA super-molecule into smaller fragments by rhizosphere acidification, as well as the entrance of HA fragments into plants that exert hormone-like effects, could further support our findings [33, 34, 35].

Also the result of this study showed that the highest malondialdehyde and dityrosine content were observed irrigation withholding at flowering stage (Table 3). It is well known that peroxidation of lipid membranes of higher plants reflects free radicalinduced oxidative damage at the cellular level under abiotic stress [36, 37]. Malondialdehyde is often regarded as the product and a reflection of the degree of membrane lipid peroxidation [38]. Therefore, malondialdehyde content in the leaves corn plants was measured under water stress. With the water stress, leaf malondialdehyde content increased. Dityrosine content is often regarded as the product and a reflection of the degree of protein cell plants. The highest dityrosine was observed from stressed plants (Table 3). However, the malondialdehyde and dityrosine content in humic acid foliar application treatments remained lower than that in untreated humic acid foliar application treatment (Table 3). Also, under irrigation withholding at different growth stages, humic acid foliar application with 300 ppm decreased malondialdehyde and dityrosine content (Table 4), which shows that the antioxidant enzymes activity could alleviate the peroxidation of membrane lipids and protein in plant cells.

\section{CONCLUSION}

From the study it may be concluded that, in starter feed, the company used antifungal inclusions and less used such things in grower and finisher feeds. As fungal diseases are sensitive for commercial broilers that's why different feed company use high level of fungistat during feed processing. But, this practice is harmful for public health. The use of strong antifungals in every level of feeds (Starter, Grower and Finisher) may reduces the fungal contamination of feeds when storage at dealer and farm levels; On the other hand, the feed mill manufacturing process should be maintained properly and post processing contamination should be strictly avoided. Therefore, the occurrence of fungi in commercial broiler feeds may be due to pre and post processing contamination of feed ingredients, bad manufacturing process, contamination of the feed by handlers in the farm, bad feed storage facilities in the farm among others. Due to this fact, regular microbiological and mycotoxicological analysis should be performed for maintaining quality and safety of poultry feed.

\section{REFERENCES}

1. Bannayan $\mathrm{M}$ et al 2008: Yield and seed quality of Plantago ovata and Nigella sativa under different irrigation treatments. Industrial Crops and Products 27(1) 11-16.

2. Zhu JK 2000: Genetic analysis of plant salt tolerance using Arabidopsis. Plant Physiol. 124 941-948.

3. Noctor G and Foyer CH 1998: Ascorbate and glutathione: keeping active oxygen under control. Annu. Rev. Plant Physiol. Plant Mol. Biol. 49 249-279.

4. Abdel Latef AA 2010: Changes of antioxidative enzymes in salinity tolerance among different wheat cultivars. Cereal Res. Comm. 38 43-55.

5. Meloni DA, Oliva MA, Martinez CA and Cambraia J 2003: Photosynthesis and activity of superoxide dismutase, peroxidase and glutathione reductase in cotton under salt stress. Environ. Exp. Bot. 49 69-76.

6. Mackowiak CL, Grossl PR and Bugbee BG 2001: Beneficial effects of humic acid on micronutrient availability to wheat. Soil Sci. Soc. Am. J. 65 1744-1750.

7. Karakurt Y, Unlu H and Padem H 2009: The influence of foliar and soil fertilization of humic acid on yield and quality of pepper. Acta Agriculture Scandinavica Section B. Soil and Plant Science 59 233237.

8. Sangeetha M, Singaram P, Devi RD 2006: Effect of lignite humic acid and fertilizers on the yield of onion and nutrient availability. Proceedings of 18th World Congress of Soil Science July 9-15, Philadelphia, Pennsylvania, USA.

9. Asli S, Neumann PM 2010. Rhizosphere humic acid interacts with root cell walls to reduce hydraulic conductivity and plant development. Plant and Soil 336 313-322.

10. Cordeiro FC, Santa-Catarina C, Silveira V, De Souza SR 2011: Humic acid effect

1. on catalase activity and the generation of reactive oxygen species in corn (Zea Mays L.). Biosci. Biotechnol. Biochem. 75 70-74. 
11. Arnon DI 1949: Copper enzymes in isolated chloroplasts, polyphennol oxidase in Beta vulgaris. Plant Physiol. 24 1-150.

12. Cakmak I and Horst W 1991: Effect of aluminium on lipid peroxidation, superoxide dismutase, catalase and peroxidase activities in root tip of soybean (Glycine Max L.). Plant Physiol. 83 463468.

13. Giannopolitis C and Ries S 1977: Superoxide dismutase occurrence in higher plant. Plant Physiol. 59 309-314.

14. Paglia DE and Valentine WN 1997: Studies on the quantitative and quantitative traits of glutathione peroxidase. Dase. J. Lab. Med 70 158-165.

15. De Vos C, Schat HM, De Waal MA, Vooijs $\mathrm{R}$ and Ernst W 1991: Increased to copper induced damage of the root plasma membrane in copper tolerant Silene Cucubalus. Plant Physiol. 82 523-528.

2. 16. Amado R, Aeschbach R, Neukom, H.1984: Dityrosine: in vitro production and characterization. Methods Enzymol 107 377-388.

16. SAS Institute Inc 2002: The SAS System for Windows, Release 9.0. Statistical Analysis Systems Institute, Cary, NC, USA.

17. Mwanamwenge J, Long SP, Siddique KHM and Cocks PS 1999: Effect of water stress during floral initiation, flowering and podding on the growth and yield of faba bean (Vicia faba L.). European Journal of Agronomy 11 1-11.

18. Unger PW 1992: Time and frequency of irrigation effects on sunflower production and water use. Soil Sci. Soc. Am. J. 46 1072-1076.

19. Yari L, Modarres MA, Sorushzade A 2005: The effect of foliar application of $\mathrm{Mn}$ and $\mathrm{Zn}$ on qualitative characters in five spring safflower cultivars. J. Water and Soil Sci. 18 143-151.

20. Levitt J 1980: Responses of plants to environmental stresses. Academic Press, New York.

21. Jabari F, Ahmadi A, Poostini $\mathrm{K}$ and Alizadeh H 2006: Study of relationship of activities of some antioxidant enzymes with cell membrane stability and chlorophyll of drought-resistant and drought-sensitive bread wheat cultivars. J. of Agric. Sci. 1(2) 307-316.

22. Jiang $Y$ and Huang N 2001: Drought and heat stress injury to two cool season turf grasses in relation to antioxidant metabolism and lipid peroxidation. Crop Sci. 41 436- 442.

23. Liang Y, Chen Q, Liu Q, Zhang W, Ding R 2003: Exogenous silicon increases antioxidant enzyme activity and reduces lipid peroxidation in roots of salt stressed barley (Hordeum Vulgar L.). J. Plant Physiol. 160 1157- 1164.

24. Reddy AR, Chaitanya KV, Sundar D 2000: Water stress mediated changes in antioxidant enzymes activity of mulberry (Morus alba L.). J Seri Sci Jpn 69 169-175.

25. Chaitanya KV, Sundar D, Masilamani S, et al 2002: Variation in heat stress-induced antioxidant enzyme activities among three mulberry cultivars. Plant Growth Regul 36 175-180.

26. Mittler R 2002: Oxidative stress, antioxidants and stress tolerance. Trends Plant Sci 7 405-410.

27. Sankar B, Jaleel CA, Manivannan P, Kishorekumar A, Somasundaram R, Panneerselvam, R 2007: Effect of paclobutrazol on water stress amelioration through antioxidants and free radical scavenging enzymes in Arachis hypogaea L. Colloid Surf B Biointerf 60 229-235.

28. Tahi H, Wahbi S, Modafar CE, Aganchich A, Serraj R 2008: Changes in antioxidant activities and phenol content in tomato plants subjected to partial root drying and regulated deficit irrigation. Plant Biosyst 142 550-562.

29. Shao HB, Liang ZS, Shao MA 2005: Changes of anti-oxidative enzymes and MDA content under soil water deficits among 10 wheat (Triticum aestivum L.) genotypes at maturation stage. Colloid Surf B Biointerf 45 7-13.

30. Turkan I, Bor M, Ozdemir F, Koca H 2005: Differential responses of lipid peroxidation and antioxidants in the leaves of drought tolerant $P$. actifolius Gray and drought sensitive $P$. vulgaris $\mathrm{L}$. subjected to polyethylene glycol mediated water stress. Plant Sci 168 223-231.

31. Sanchez-Rodriguez ES, Wilhelmi MMR, Cervilla LM, Blasco B, Rios JJ, Rosales 
MA, Romero L, Ruiz JM 2010: Genotypic differences in some physiological parameters symptomatic for oxidative stress under moderate drought in tomato plants. Plant Sci 178 30-40.

32. Canellas LP, Piccolo A, Dobbss LB, Spaccini R, Olivares FL, Zandonadi DB, Facanha AR 2010: Chemical composition and bioactivity properties of size-fractions separated from a vermicompost humic acid. Chemosphere 78 457-466

33. Dobbss LB, Canellas LP, Olivares FL, Aguiar NO, Peres LEP, Azevedo M, Spaccini R, Piccolo A, Facanha AR 2010: Bioactivity of chemically transformed humic matter from vermicompost on plant root growth. J. Agric. Food Chem. 58 36813688 .

34. Suthar S 2010: Evidence of plant hormone like substances in vermiwash: an ecologically safe option of synthetic chemicals for sustainable farming. Ecol. Eng. 36 1089-1092.

35. Hernandez JA, Olmos E, Corpas FJ, Sevilla F, Del-Rio LA 1995: Salt-induced oxidative stress in chloroplasts of pea plants. Plant Sci 105 151-167.

36. Nouairi I, Ben Ammar W, Ben Youssef N, Ben Miled DD, Ghorbal MH, Zarrouk M. 2009: Antioxidant defense system in leaves of Indian mustard (Brassica juncea) and rape (Brassica napus) under cadmium stress. Acta Physiol Plant 31 237-247.

37. Ali MB, Hahn E, Paek K 2005: Effects of temperature on oxidative stress defense systems, lipid peroxidation and lipoxygenase activity in Phalaenopsis. Plant Physiol Biochem. 43 213-223. 